\title{
Pengembangan Model Efektifitas Kebijakan Ekonomi Berbasis Tax Amnesty untuk Meningkatkan Kepatuhan Wajib Pajak di Indonesia
}

\author{
Suratno ${ }^{1}$, Nurmala Ahmar ${ }^{2}$, Monang Nixon Haposan Tampubolon ${ }^{3}$, Riki \\ Sumarsyah 4 \\ 1,2,3,4 Universitas Pancasila, Jakarta, Indonesia
}

\section{INFO ARTIKEL JEL Classification :}

$\mathrm{H} 26, \mathrm{H} 32$

\section{Keywords :}

compliance, corporate taxprayer, economic policy, tax amnesty

\begin{abstract}
The purpose of this study is to analyze and investigate the implementation of tax amnesty, and to develop a tax amnesty effectiveness model to improve corporate taxpayer compliance. The sample is 639 companies listed on the Indonesia Stock Exchange and divided into 9 industrial groups. The type of data used is secondary data. Tax amnesty data is obtained from information on the implementation of PSAK 70 in the notes to the financial statements and the presentation of tax payable due to tax amnesty in the statement of financial position. This shows that there is still a gap in the participation status of the tax amnesty program based on the industrial sector and sub-sector. This is supported by the observation of participation status, where the overall level of participation in the tax amnesty program only shows $35.1 \%$ and those who have not participated are $64.9 \%$. These findings indicate that there is a potential tax revenue of $64.9 \%$ from the tax amnesty policy. Based on the research results, the tax amnesty policy is still needed based on the research results that the tax potential for the policy is more than $50 \%$.
\end{abstract}

\begin{abstract}
ABSTRAK
Tujuan penelitian ini adalah melakukan analisis dan menginvestigasi implementasi tax amnesty, dan mengembangkan model efektifitas tax amnesty untuk meningkatkan kepatuhan wajib pajak badan. Sampel adalah 639 perusahaan yang terdaftar di Bursa Efek Indonesia dan terbagi dalam 9 kelompok industri Jenis data yang digunakan adalah data sekunder. Data tax amnesty diperoleh dari informasi implementasi PSAK 70 pada catatan atas laporan keuangan dan penyajian utang pajak akibat tax amnesty di laporan posisi keuangan. Hal ini menunjukkan bahwa masih ada kesenjangan/perbedaan status partisipasi program tax amnesty berdasarkan sektor maupun subsektor industri. Hal ini terdukung observasi status partisipasi dimana secara keseluruhan tingkat partisipasi pprogram tax amnesty baru menunjukkan $35,1 \%$ dan yang belum berpartisipasi sebanyak $64,9 \%$. Temuan ini menunjukkan bahwa terdapat potensi penerimaan pajak sebesar $64,9 \%$ dari kebijakan tax amnesty. Berdasarkan hasil penelitian, kebijakan tax amnesty masih diperlukan didasarkan pada hasil penelitian bahwa potensi pajak untuk kebijkan tersebut lebih dari 50\%.
\end{abstract}




\section{Pendahuluan}

Kebijakan ekonomi berbasis pengampunan pajak yang dilakukan pemerintah dari sisi deklarasi berhasil karena melebihi target Rp4.000 triliun namun repatriasi dianggap gagal karena hanya mencapai kurang dari $15 \%$ dari target Rp1.000 triliun (www. bbc.com). Institute for Development of Economics and Finance (Indef) menilai program pengampunan pajak (tax amnesty) kurang berhasil. Ada 4 indikator yang digunakan Indef. Indikator tersebut yakni tingkat likuiditas domestik, perbaikan nilai tukar rupiah, penurunan suku bunga, dan peningkatan investasi. Keempat indikator itu tertera dalam Pasal 2 ayat 2 UU No. 11 Tahun 2016 tentang Pengampunan Pajak (kompas.com). Banyak negara lain melakukan kebijakan yang sama untuk mendorong peningkatan pendapatan negara dari sector pajak. Bahkan kebijakan tersebut dilakukan secara berulang. Bangladesh melakukan sebanyak 18 kali selama 2 tahun, India 11 kali selama tahun 2016, Srilanka 11 kali selama tahun 2013, Kazakhstan 3 kali selama tahun 2014 sampai dengan 2016. Indonesia telah melakukan sebanyak 4 kali, tahun 1961-1965 melalui program official assessment, tahun 1984 melalui program self assessment, tahun 2008 sunset policy, dan tahun 2016 mengeluarkan undang-undang tax amnesty. Khusus pada tahun 2016, Ikatan Akuntan Indonesia menerbitkan standar akuntansi nomor 70 (PSAK 70) khusus untuk pengampunan pajak sebagai pedoman bagi perusahaan untuk melakukan pencatatan dan penyajian laporan kegiatan tax amnesty tersebut.

Kebijakan pengampunan pajak digunakan banyak negara untuk memperbaiki penerimaan negara dari sumber pajak. Santoso dan Setiawan (2009) menemukan hanya sedikit negara yang berhasil dalam program tax amnesty, karena pemerintah tidak mengantisipasi perbaikan struktural pasca amnesty yang mencakup kebijakan ekonomi, sistem perpajakan dan penerapan law enforcement. Kebijakan tax amnesty yang ditawarkan berulang-ulang secara jangka panjang berakibat menurunkan kepatuhan suka rela wajib pajak dan tidak dapat menaikkan basis pajak. Keberhasilan tax amnesty di Afrika Selatan pada tahun 2003 berasal dari kebijakan amnesty berupa pengontrolan devisa untuk mengembalikan dana yang diparkir di luar negeri dengan diskon tarif amnesty yang menarik, selain itu SARS melakukan pendekatan yang bersahabat dengan wajib pajak dalam program kampanye taat pajak. Sedangkan tax amnesty di Irlandia dapat berhasil karena pemerintah telah siap dengan kebijakan pendukung pasca tax amnesty untuk meningkatkan law enforcement dengan menambah jumlah pemeriksa pajak dan memberlakukan sistem perpajakan yang baru pasca amnesty, dengan ancaman sanksi sampai penyitaan asset dan pembekuan rekening bank bagi penyelundup pajak. Tax amnesty yang dilakukan secara rutin di India terbukti gagal, tetapi tax amnesty yang dilakukan pada tahun 1997 dapat berhasil menaikkan basis pajak karena program ini ditegaskan sebagai program amnesty yang terakhir dan ditawarkan di tengah inflasi yang terjadi.

Penelitian ini penting untuk dilakukan dengan pertimbangan hasil penelitian berupa publikasi ilmiah kebijakan terkait model kebijakan ekonomi berbasis tax amnesty dapat memberikan masukan kepada pemerintah untuk dasar pengambilan kebijakan dimasa mendatang. Basis data tentang kepatuhan terhadap program tax amnesty dapat digunakan dasar pengawasan kepatuhan wajib pajak. badan khususnya terkait program tax amnesty dan implementasi standar akuntansi keuangan tentang pengampunan pajak. PSAK 70 mengatur akun-akun yang terpengaruh oleh pelaksanaan pengampunan pajak yaitu aset tambahan, selisih antara aset dan liabilitas tambahan akan dibukukan sebagai tambahan modal disetor.

\section{Telaah Teori dan Pengembangan Hipotesis}

Amnesti pajak bisa menjadi alat kebijakan pajak. Amnesti juga dapat digunakan secara sistematis sebagai mekanisme diskriminatif untuk meningkatkan efisiensi atau bahkan pemerataan sistem pajak (Marchese, 2014). Kebijakan ini dapat muncul kembali untuk kepentingan-kepentingan tertentu, misalnya 
untuk kepentingan politik. Pada akhirnya tax amnesty hanya merupakan alat kebijakan (Bose dan Jetter, 2012). Namun, melalui kebijakan tax amnesty, pemerintah dapat melakukan deteksi terhadap wajib pajak nakal, meningkatkan pendapatan dan kesejahteraan masyarakat dari sector pajak.

Amnesty pajak dapat memicu kepatuhan wajib pajak (Alfiyah dan Latifah, 2016; Yasa dan Mandala, 2016). Temuan berbeda oleh Suyanto dan Putri (2017) membuktikan bahwa persepsi wajib pajak tentang kebijakan tax amnesty tidak memiliki pengaruh yang positif terhadap kepatuhan perpajakan, dan motivasi wajib pajak memiliki pengaruh positif terhadap kepatuhan perpajakan.

Yasa dan Mandala (2016) mengatakan bahwa penerapan tax amnesty berimplikasi terhadap beberapa hal diantaranya, peningkatan jumlah wajib pajak, peningkatan penerimaan pendapatan negara, dan membantu mempercepat pembangunan infrastruktur untuk mempermudah masyarakat melakukan aktivitas ekonomi, sehingga berharap kesejahteraan meningkat. Ragimun (2013) mengatakan bahwa penerapan tax amnesty di Indonesia masih merupakan wacana yang pro dan kontra pada tahun 2012. Pada dasarnya penerapan kebijakan ini diharapkan dapat meningkatkan jumlah wajib pajak, subyek dan obyek pajak sekaligus meningkatkan penerimaan negara dari dana-dana yang di "parkir" di luar negeri.

Kepatuhan dan penghindaran pajak adalah keputusan yang kompleks yang dimotivasi oleh berbagai faktor. Adanya ancaman hukuman, pemeriksaan bagi yang tidak mengikuti program kebijakan pajak (tax amnesty) menyebabkan tingkat kepatuhan meningkat. Cummings, et al (2009) dan Nar (2015) menghubungkannya dengan prospect theory dan rank-dependent expected utility. Teori tersebut menyatakan bahwa orang membuat keputusan berdasarkan nilai kerugian dan keuntungan potensial daripada hasil akhir, dan orang mengevaluasi kerugian dan keuntungan ini dengan menggunakan cara penemuan (heuristic) tertentu. Wajib pajak akan menghitung untuk dan rugi bagi mereka jika mengikuti tax amnesty. Mereka akan berperilaku seolah-olah mereka akan menghitung nilai (utilitas), berdasarkan hasil potensial dan probabilitas masing-masing, dan kemudian memilih alternatif yang memiliki utilitas lebih tinggi.

Di lain pihak ketidakikutsertaan dalam program tax amnesty juga akan menjadi pemicu sanksi norma social. Cyan, et al (2016), Sari dan Fidiana (2017) bahkan membuktikan bahwa tingkat pendidikan mempengaruhi kepatuhan wajib pajak. Tingkat pemahaman terkait erat dengan tingkat pengetahuan. Akuntan sebagai warga Negara yang berpendidikan seharusnya mendukung kebijakan pemerintah tersebut. Setyaningsih dan Oktifitasari (2012) mencoba melakukan eksplorasi pendapat wajib pajak, temuannya adalah pajak masih merupakan sebentuk gangguan dan menimbulkan ketakutan di masyarakat. Membuat potongan pajak untuk pembayar pajak, yang membayar pajak mereka secara teratur, dapat dianggap sebagai "keadilan yang berasal dari ketidakadilan" secara parsial meskipun ada sesuatu yang menarik pada temuan Tofan (2017), dimana wajib pajak yang disiplin menganggap dirinya tidak beruntung. Pada sudut pandang yang berbeda, Bose dan Jetter (2012) berpendapat bahwa kondisi ekonomi yang baik mungkin juga memberi motivasi untuk memberikan amnesti.

Indonesia telah menerapkan amnesti pajak pada tahun 1964, 1984 dan 2016. Amnesti pajak pada tahun 1964 dan 1984 dianggap tidak berhasil karena kondisi politik pada saat itu dan ketidaktahuan pemerintah terhadap program tersebut. Ini sangat berbeda dengan Afrika Selatan, India, dan Italia yang berhasil menerapkan program amnesti pajak (Huda dan Hernoko, 2017. Pengampunan pajak secara berulang merupakan kajian yang menarik. Shevlin, et al (2017) menunjukkan bahwa program pengampunan pajak yang berulang kali memiliki implikasi yang semakin negatif terhadap koleksi pajak perusahaan. Wang dan Hsieh (2015) memberikan pertimbangan lain, dimana orang-orang yang berpartisipasi dalam program amnesti pajak mungkin tidak secara jujur melaporkan keseluruhan jumlah pajak yang terhindar, hal itu menyebabkan penghindaran pajak sekunder. Berdasarkan data dengan kurun waktu panjang (19812011) Bayer, et al (2015) menemukan kecenderungan perilaku wajib pajak yang mengharapkan akan terjadi kembali tax amnesty. Riset ini juga membuktikan bahwa 
motivasi kebijakan tax amnesty oleh pemerintah didominasi oleh kepentingan target pemenuhan pendapatan negara dalam jangka pendek. Wajib pajak seolah meyakini bahwa kebutuhan pemenuhan anggaran pendapatan pemerintah dari pajak di masa depan berdampak pada kebijakan tax amnesty ulang di masa mendatang.

Program amnesti pajak di Bangladesh telah menciptakan efek yang merugikan pada ekonomi Negara (Waris dan Latif, 2014) Pembayar pajak yang mengikuti program amnesti pajak dilindungi oleh pemerintah meskipun mereka hanya melaporkan $1 \%$ dari uang hitam mereka. Amnesti pajak di Italia secara informal dikenal sebagai 'perisai pajak' (scudo fiscale) berdasarkan perlindungan yang diberikan kepada pembayar pajak yang secara sukarela mengungkapkan atau memulangkan aset asing yang tidak diumumkan. (Panico, 2010).

Bagaimana pasar bereaksi atas kebijakan amnesty pajak? Dampak peristiwa amnesty pajak dibuktikan dengan menguji reaksi pasar di Indonesia dilakukan oleh Asmorojati, dkk (2017) dan Wibowo dan Darmanto (2017). Abnormal return dan aktivitas volume perdagangan saham sebelum dan sesudah peristiwa berlakunya Undang-Undang Tax amnesty paa perusahaan LQ-45 selama periode periode Februari 2016-Juli 2016 mengalami penurunan. dan rata-rata volume aktivitas perdagangan (TVA) yang mengindikasikan bahwa Investor pasar modal Indonesia tidak bereaksi positif terhadap kejadian amnesti pajak (Asmorojati, dkk, 2017). Hal berbeda ditemukan oleh Wibowo dan Darmanto (2017, dimana terjadi peningkatan rata-rata abnormal kembali antara tanggal acara dan pasca acara pelaksanaan amnesti pajak dan pra event dan pasca acara pelaksanaan amnesti pajak, namun di sisi lain ada penurunan aktivitas rata-rata volume perdagangan (TVA), hal tersebut menunjukkan bahwa kenaikan abnormal return hanya pseudo, karena tidak disertai dengan kenaikan volume aktivitas perdagangan, sehingga dapat disimpulkan bahwa tidak ada reaksi investor pasar modal Indonesia terhadap terjadinya amnesti pajak.

Ahmar (2018) membuktikan bahwa akuntan public memiliki peran penting dalam keberhasilan tax amnesty di Indonesia pada perusahaan lembaga keuangan dan perbankan. Temuan riset adalah banyak emiten pada sector jasa keuangan yang diaudit oleh KAP Non-Big 4 banyak mengungkap implementasi PSAK 70. Hal sebalinya untuk KAP Big-4. Pertanyaan besar muncul, bagaimana peta implementasi PSAK 70 sebagai refleksi kepatuhan pajak terkait tax amnesty untuk sector industri lainnya. Temuan riset tersebut sangat penting untuk pertimbangan pengulangan kebijakan ekonomi yang sejenis pada masa mendatang.

\section{Metode Penelitian}

Riset ini merupakan riset kuantitatif dan merupakan riset dasar, karena bertujuan menguji hipotesis untuk memperoleh pembuktian empiris. Sampel adalah perusahaan yang terdaftar di Bursa Efek Indonesia. Jenis data yang digunakan adalah data sekunder. Data tax amnesty diperoleh dari informasi implementasi PSAK 70 pada catatan atas laporan keuangan dan penyajian utang pajak akibat tax amnesty di laporan posisi keuangan. Informasi bersumber dari dokumen daring yang diterbitkan dan dipublikasikan pada www. idx.co.id Metode pengumpulan data adalah metode dokumentasi. Dokumen yang dimaksud adalah dokumen publikasi laporan keuangan dalam bentuk catatan atas laporan keuangan dan laporan posisi keuangan.

Variable penelitian adalah status sektor industri diukur dengan kode nomor 1 sampai dengan 7 , dimana $1=$ pertanian, $2=$ keuangan, $3=$ aneka industri, $4=$ industri dasar dan kimia, $5=$ indusri barang konsumsi, $6=$ infrastruktur, utilitas \& transportasi, 7=properti, perumahan \& konstruksi bangunan, 8= tambang, 9= layanan perdagangan dan investas Status tax amnesty diukur dengan dummy variable, 1 diberikan kepada sampel yang menyajikan informasi implementasim PSAK 70 dan menyajikan dampak implementasi tersebut di laporan posisi keuangan, dan 0 bagi yang tidak.

Pengujian dilakukan dengan tabulasi silang (crosstabulation) dan Uji Cramer-V. Uji Cramer-V digunakan untuk menguji hubungan antara 2 variabel yang diukur secara nominal. Analisis dikembangkan dengan menguji per kelompok industri berdasarkan pengungkapan PSAK 70 di laporan keuangan. 


\section{Hasil Penelitian dan Pembahasan}

Penelitian ini menguji pengaruh peristiwa pengampunan pajak pada perusahaan publik yang terdaftar di Bursa Efek Indonesia. Kementerian Keuangan mendefinisikan pengampunan pajak merupakan penghapusan pajak yang seharusnya terutang, tidak dikenai sanksi administrasi perpajakan dan sanksi pidana di bidang perpajakan. Kewajiban perpajakan yang mendapatkan Pengampunan Pajak terdiri atas kewajiban Pajak Penghasilan, dan Pajak Pertambahan Nilai atau Pajak Pertambahan Nilai dan Pajak Penjualan atas Barang Mewah. Pengampunan Pajak merupakan terobosan kebijakan yang memiliki manfaat dan tujuan sebagai berikut :

- Meningkatkan pertumbuhan ekonomi melalui Repatriasi Aset, yang ditandai dengan peningkatan likuiditas domestik, perbaikan nilai tukar rupiah, penurunan Suku Bunga, dan peningkatan investasi.

- Perluasan basis data perpajakan yang lebih valid, komprehensif dan terintegrasi.

- Meningkatkan Penerimaan Pajak.

Standar akuntansi keuangan yang diterbitkan oleh Ikatan Akuntan Indonesia (IAI) mengatur perlakuan akuntansi penganpunan pajak pada Pernyataan Standar Akuntansi 70 (PSAK 70). Riset ini menginvestigasi kepatuhan pengampunan pajak berdasarkan pengungkapan emiten pada laporan keuangan. Investigasi dilakukan pada pengungkapan (disclosure) laporan keuangan tahun 2016 yang diterbitkan pada tahun 2017. Mengacu pada manfaat dan tujuan program pengampunan pajak, penelitian memberikan manfaat tambahan antara lain:

- Menemukan potensi penerimaan pajak dimasa mendatang terkat kebijakan ulang tax amnesty

- Menjadi dasar kebijakan insentif pengampunan pajak berikutnya

- Mengetahui kepatuhan wajib pajak badan melalui partisipasi emiten di Bursa Efek Indonesia dalam program tax amnesty berdasarkan pengungapan PSAK 70 pada laporan keuangannnya.

Hasil penelitian tidak sekedar merupakan perluasan basis data perpajakan yang lebih valid, komprehensif dan terintegrasi, namun juga dapat diperoleh basis data emiten di pasar modal yang berstatus melakukan tax amnesty dan tidak melakukan tax amnesty. Basis data ini dapat digunakan sebagai dasar untuk melakukan pemeriksaan pajak oleh Dirjen Pajak.

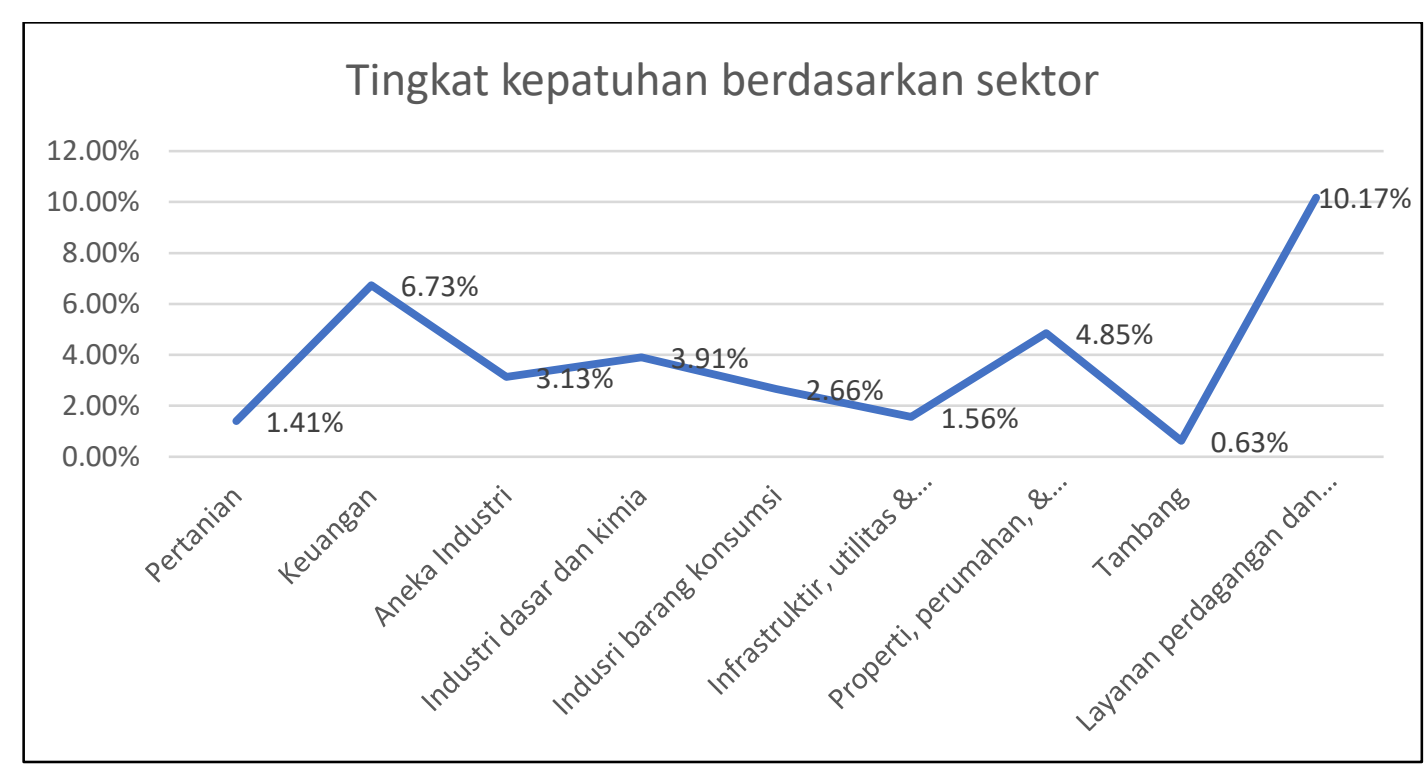

Gambar 1. Tingkat kepatuhan (tax amnesty) berdasarkan sektor industri

Riset ini mengembangan model kepatuhan wajib pajak badan didasarkan PSAK 70 tentang pengampunan pajak. PSAK 70 merupakan pedoman perushaan publik dalam menyajikan laporan keuangan. Sampel riset ini adalah perusahaan yang terdaftar di Bursa Efek Indonesia (BEI). Pemilihan 
sampel emiten di BEI dilakukan dengan pertimbangan bahwa deteksi kepatuhan dalam berpartisipasi dalam program tax amnesty dapat dideteksi dengan jelas karena diatur dalam PSAK 70.

Penyusunan laporan keuangan memerlukan pedoman terkait penilaian, pengukuran, pencatatan dan penyajiannya. Hal terpenting yang juga harus diperhatikan oleh emiten sebagai wajib pajak badab adalah kewajiban melakukan mengungkapan dalam catatan atas laporan keuangan atas akun-akun yang disajikan dan peristiwaperistiwa penting dalam satu periode akuntansi, termasuk keikutsertaan dalam program tax amnesty karena emiten wajib mengngkapkan perlakuan akuntansi atas aset pengampunan pajak dan dampaknya.

Efektifitas pengembangan model diuji dengan uji Cramer-V berdasarkan kelompok sektor industri dan subsektor industri. Hasil pengujian berdasarkan sektor industri dan subsektor industri adalah sebagai berikut:

Tabel 1: Uji efektifititas model berdasarkan sektor industri

\begin{tabular}{lll} 
Uji & Value & $\begin{array}{l}\text { Approximate } \\
\text { Significance }\end{array}$ \\
\hline Phi & 0,240 & 0,000 \\
Cramer's V & 0,240 & 0,000 \\
Jumlah sampel & & 639 \\
\hline
\end{tabular}

Tabel 2: Uji efektifitas model berdasarkan sub seltor industri

\begin{tabular}{lll} 
Uji & Value & $\begin{array}{l}\text { Approximate } \\
\text { Significance }\end{array}$ \\
\hline Phi & 0,329 & 0,015 \\
Cramer's V & 0,329 & 0,015 \\
Jumlah sampel & & 639 \\
\hline
\end{tabular}

Hasil pengujian menunjukkah temuan yang konsisten baik berdasarkan sektor industri maupun sub sektor industri. Hal ini menunjukkan bahwa masih ada kesenjangan/perbedaan status partisipasi program tax amnesty berdasarkan sektor maupun subsektor industri. Hal ini terdukung observasi status partisipasi dimana secara keseluruhan tingkat partisipasi pprogram tax amnesty baru menunjukkan $35,1 \%$ dan yang belum berpartisipasi sebanyak 64,9\%. Temuan ini menunjukkan bahwa terdapat potensi penerimaan pajak sebesar $64,9 \%$ dari kebijakan tax amnesty. Emiten di BEI sebagai wajib pajak badan yang diasumsikan memiliki kemampuan membayar pajak dan mematuhi regulasi dengan potensi termonitor merupakan wajib pajak yang patut menjadi contoh wajib pajak lain yang belum terdaftar di BEI.

Temuan ini dapat dijadikan rekomendasi bahwa kebijakan program tax amnesty jilid berikutnya masih diperlukan oleh Dirjen Pajak untuk memperoleh pendapatan dari sektor pajak sebagai pendapatan porsi terbesar penerimaan negara. Kebijakan tersebut dapat dilakukan secara mandatory, khususnya emiten di BEI.

\section{Kesimpulan, Keterbatasan dan Implikasi Hasil Penelitian}

Riset ini mengembangan model kepatuhan wajib pajak badan didasarkan PSAK 70 tentang pengampunan pajak. PSAK 70 merupakan pedoman perushaan publik dalam menyajikan laporan keuangan. Sampel riset ini adalah perusahaan yang terdaftar di Bursa Efek Indonesia (BEI). Pemilihan sampel emiten di BEI dilakukan dengan pertimbangan bahwa deteksi kepatuhan dalam berpartisipasi dalam program tax amnesty dapat dideteksi dengan jelas karena diatur dalam PSAK 70. Efektifitas pengembangan model diuji dengan uji Cramer-V berdasarkan kelompok sektor industri dan subsektor industri.

Hasil pengujian menunjukkah temuan yang konsisten baik berdasarkan sektor industri maupun sub sektor industri. Hal ini menunjukkan bahwa masih ada kesenjangan/perbedaan status partisipasi program tax amnesty berdasarkan sektor maupun subsektor industri. Hal ini terdukung observasi status partisipasi dimana secara keseluruhan tingkat partisipasi pprogram tax amnesty baru menunjukkan $35,1 \%$ dan yang belum berpartisipasi sebanyak $64,9 \%$. Temuan ini menunjukkan bahwa terdapat potensi penerimaan pajak sebesar $64,9 \%$ dari kebijakan tax amnesty. Emiten di BEI sebagai wajib pajak badan yang diasumsikan memiliki kemampuan membayar pajak dan mematuhi regulasi dengan potensi termonitor merupakan wajib pajak yang patut menjadi contoh wajib pajak lain yang belum terdaftar di BEI.

Temuan ini dapat dijadikan rekomendasi bahwa kebijakan program tax amnesty jilid berikutnya masih diperlukan oleh Dirjen Pajak untuk memperoleh pendapatan dari 
sektor pajak sebagai pendapatan porsi terbesar penerimaan negara. Kebijakan tersebut dapat dilakukan secara mandatory, khususnya emiten di BEI.

\section{Daftar Pustaka}

Ahmar, N, (2018), The Role of Public Accountant on The Success of Tax amnesty in Financial Institution and Banking, International Seminar and Call for Paper on Accounting and Society, Jakarta.

Alfiyah, N. and Latifah, S. W. (2017) 'Pengaruh Pelaksanaan Kebijakan Sunset Policy, Tax amnesty , Kepatuhan Wajib Pajak', 7(2), pp. 1081-1090.

Asmorojati, W., Diana, N. and Afifudin (2016) 'Reaksi Investor Terhadap Pengumuman Kebijakan Tax amnesty Pada Tanggal 1 Juli 2016', e-Jurnal Ilmiah Riset Akuntansi, 2016(2), pp. 2741.

Bayer, R., Oberhofer, H. and Winner, H. (2015) 'The occurrence of tax amnesties: Theory and evidence to', Journal of Public Economics. Elsevier B.V., 125, pp. 70-82.

Bbc. (2017, 31 Maret), Amnesti pajak: Deklarasi berhasil namun repatriasi gagal, diperoleh 30 september dari https://www.bbc.com/indonesia/indonesi a-39446034.

Bose, P. and Jetter, M. (2012) 'Liberalization and tax amnesty in a developing economy", Economic Modelling. Elsevier B.V., 29(3), pp. 761-765.

Cummings, R. G. et al. (2009) 'Tax morale affects tax compliance: Evidence from surveys and an artefactual field experiment', Journal of Economic Behavior and Organization, 70(3), pp. 447-457.

Cyan, M. R., Koumpias, A. M. and MartinezVazquez, J. (2016) 'The determinants of tax morale in Pakistan', Journal of Asian Economics. Elsevier Inc., 47, pp. 23-34. Faculty, M. T. (2017) 'Tax Amnesty For Social Contribution In Romanian', (11), pp. 190-197.
Kompas, (2017, 6 April), Dari sejumlah indikator ini, tax amnesty dinilai gagal, diperoleh 30 September dari https://ekonomi.kompas.com/read/2017/0 4/06/163000626.

Marchese, C. (2014) 'Tax Amnesties', (March), p. 19. Available at: http://www.iel.carloalberto.org/Research -and-Pubblication/Working-papers.aspx.

Panico, P. (2010) 'An appraisal of trusts under the Italian tax amnesty', E Biling, 16(4), pp. 247-249. doi: 10.1093/tandt/ttq017.

Ragimun (2013) 'Analisis Implementasi Pengampunan Pajak (Tax amnesty) Di Indonesia', International Tax Review, (122), pp. 2016-2018.

Santoso, U. and Setiawan, J. M. (2009) 'Tax amnesty', Sosiohumaniora, 11(2), pp. $111-125$.

Sari, V. A. Permata and Fidiana, F. (2017) 'Pengaruh Tax amnesty, Pengetahuan Perpajakan , Dan Pelayanan Fiskus Terhadap Kepatuhan Wajib Pajak', Perpajakan, 6, pp. 745-760.

Setyaningsih, T. and Okfitasari, A. (2016) 'Mengapa Wajib Pajak Mengikuti Tax amnesty (Studi Kasus Di Solo)', Ekuitas: Jurnal Ekonomi dan Keuangan, 20(4), pp. 415-433.

Shevlin, T., Thornock, J. and Williams, B. (2017) 'An examination of firms' responses to tax forgiveness', Review of Accounting Studies, 22(2), pp. 577-607.

Suyanto, S. and Putri, I. S. (2017) 'Pengaruh Persepsi Wajib Pajak Tentang Kebijakan Tax amnesty (Pengampunan Pajak), Dan Motivasi Membayar Pajak Terhadap Kepatuhan Perpajakan', Jurnal Akuntansi, 5(1), p. 49.

Tofan, M. (2017, October). Tax Amnesty For Social Contribution In Romanian Legal Framework. In Proceedings of Law and Political Sciences Conferences (No. 6208058). International Institute of Social and Economic Sciences.

Wang, Y. and Hsieh, W. (2015) 'Is Tax amnesty Good for the Tax Evader?', British Journal of Economics, Management \& Trade, 6(4), pp.

Magister Akuntansi Universitas Pancasila 
Suratno, Nurmala Ahmar, Monang Nixon Haposan Tampubolon, Riki Sumasyah: Pengembangan Model Efektifitas Kebijakan Ekonomi Berbasis Tax Amnesty untuk Meningkatkan Kepatuhan Wajib Pajak ...

Waris, A. and Abdul Latif, L. (2014) 'The effect of tax amnesty on anti-money laundering in Bangladesh', Journal of Money Laundering Control, 17(2), pp. $243-255$.

Wibowo, A. and Darmanto, S. (2017) 'Reaction of Indonesian Capital Market
Investors to the Implementation of Tax amnesty', Jurnal Keuangan dan Perbankan, 21(40), pp. 597-608.

Yasa, I. N. P. and Mandala, I. P. W. (2016) 'Tax amnesty dan Implementasinya (Sebuah Pendekatan Eksploratif )', 1(1), pp. $40-49$. 